\title{
Absorption Angstrom Exponent in AERONET and related data as an indicator of aerosol composition
}

\author{
P. B. Russell ${ }^{1}$, R. W. Bergstrom ${ }^{2}$, Y. Shinozuka ${ }^{3}$, A. D. Clarke ${ }^{4}$, P. F. DeCarlo ${ }^{5,6, *}$, J. L. Jimenez ${ }^{5,7}$, J. M.Livingston ${ }^{8}$, \\ J. Redemann ${ }^{2}$, O. Dubovik ${ }^{9}$, and A. Strawa ${ }^{1}$ \\ ${ }^{1}$ NASA Ames Research Center, MS 245-5, Moffett Field, CA 94035-1000, USA \\ ${ }^{2}$ Bay Area Environmental Research Institute, 560 3rd Street West, Sonoma, CA 95476, USA \\ ${ }^{3}$ Oak Ridge Associated Universities, NASA Ames Research Center, MS 245-5, Moffett Field, CA 94035-1000, USA \\ ${ }^{4}$ School of Ocean and Earth Science and Technology, University of Hawaii, Honolulu, HI, USA \\ ${ }^{5}$ Cooperative Institute for Research in the Environmental Sciences, University of Colorado, Boulder, Colorado, USA \\ ${ }^{6}$ Dept. of Atmospheric and Oceanic Sciences University of Colorado, Boulder, Colorado, USA \\ ${ }^{7}$ Dept. of Chemistry and Biochemistry, University of Colorado, Boulder, Colorado, USA \\ ${ }^{8}$ SRI International, 333 Ravenswood Avenue, Menlo Park, CA 94025, USA \\ ${ }^{9}$ Laboratoire d'Optique Atmospherique, CNRS Universite de Lille, Bat 5, 59655 Villeneuve d'Ascq CEDEX, France \\ *now at: Laboratory of Atmospheric Chemistry, Paul Scherrer Institut, Villigen, Switzerland
}

Received: 4 August 2009 - Published in Atmos. Chem. Phys. Discuss.: 16 October 2009

Revised: 8 January 2010 - Accepted: 25 January 2010 - Published: 3 February 2010

\begin{abstract}
Recent results from diverse air, ground, and laboratory studies using both radiometric and in situ techniques show that the fractions of black carbon, organic matter, and mineral dust in atmospheric aerosols determine the wavelength dependence of absorption (often expressed as Absorption Angstrom Exponent, or AAE). Taken together, these results hold promise of improving information on aerosol composition from remote measurements. The main purpose of this paper is to show that AAE values for an Aerosol Robotic Network (AERONET) set of retrievals from Sun-sky measurements describing full aerosol vertical columns are also strongly correlated with aerosol composition or type. In particular, we find AAE values near 1 (the theoretical value for black carbon) for AERONET-measured aerosol columns dominated by urban-industrial aerosol, larger AAE values for biomass burning aerosols, and the largest AAE values for Sahara dust aerosols. These AERONET results are consistent with results from other, very different, techniques, including solar flux-aerosol optical depth (AOD) analyses and airborne in situ analyses examined in this paper, as well as many other previous results. Ambiguities in aerosol composition or mixtures thereof, resulting from intermediate AAE values, can be reduced via cluster analyses that
\end{abstract}

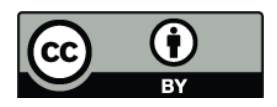

Correspondence to: P. B. Russell (philip.b.russell@nasa.gov,) supplement AAE with other variables, for example Extinction Angstrom Exponent (EAE), which is an indicator of particle size. Together with previous results, these results strengthen prospects for determining aerosol composition from space, for example using the Glory Aerosol Polarimetry Sensor (APS), which seeks to provide retrievals of multiwavelength single-scattering albedo (SSA) and aerosol optical depth (and therefore aerosol absorption optical depth (AAOD) and AAE), as well as shape and other aerosol properties. Multidimensional cluster analyses promise additional information content, for example by using the Ozone Monitoring Instrument (OMI) to add AAOD in the near ultraviolet and CALIPSO aerosol layer heights to reduce heightabsorption ambiguity.

\section{Previous results on connections between aerosol type and remotely sensible properties}

Recent research (e.g., IPCC 2007; Myhre, 2009) has emphasized that assessments of aerosol effects on climate require globally distributed information not just on aerosol amount (as conveyed, e.g., by maps of aerosol optical depth (AOD)), but also on aerosol characteristics such as size, composition and optical properties, including especially absorption. Kaufman et al. (2002) and Yu et al. (2009) have shown that it is possible to retrieve useful information on

Published by Copernicus Publications on behalf of the European Geosciences Union. 
Table 1. Attributes of the campaigns that produced the results in Figs. 1-3.

\begin{tabular}{|c|c|c|c|c|}
\hline Campaign name & Acronym & Location & Dates & Research focus \\
\hline $\begin{array}{l}\text { Tropospheric Aerosol Radiative } \\
\text { Forcing Observational Experi- } \\
\text { ment }\end{array}$ & TARFOX & US Atlantic coast & Jul 1996 & Aerosol radiative forcing \\
\hline Puerto Rico Dust Experiment & PRIDE & Puerto Rico & Jun-Jul 2000 & Sahara dust in Caribbean \\
\hline $\begin{array}{l}\text { Southern Africa Regional Sci- } \\
\text { ence Initiative }\end{array}$ & SAFARI & Southern Africa & Aug-Sep 2000 & Dry season aerosols \\
\hline $\begin{array}{l}\text { Aerosol Characterization } \\
\text { Experiment-Asia }\end{array}$ & ACE-Asia & Asian Pacific coast & Mar-May 2001 & Asian Pacific aerosol \\
\hline $\begin{array}{l}\text { International Consortium for At- } \\
\text { mospheric Research on Transport } \\
\text { and Transformation }\end{array}$ & ICARTT & New England Atlantic coast & Jul-Aug 2004 & $\begin{array}{l}\mathrm{NE} \text { US and downwind } \\
\text { aerosols }\end{array}$ \\
\hline $\begin{array}{l}\text { Megacity Initiative: Local and } \\
\text { Global Research Observations }\end{array}$ & MILAGRO & $\begin{array}{l}\text { Mexico City to Gulf of } \\
\text { Mexico }\end{array}$ & Mar 2006 & $\begin{array}{l}\text { Mexico City and downwind } \\
\text { aerosols }\end{array}$ \\
\hline
\end{tabular}

aerosol type, and indeed to help distinguish natural from anthropogenic aerosols, by using the aerosol size information contained in the wavelength dependence of AOD retrieved from the spaceborne instrument MODIS (see Appendix for acronyms). Also, many recent suborbital measurements have shown that there are persistent connections between aerosol composition and the wavelength dependence of absorption. In this section we summarize previous results relating aerosol composition and/or type to remotely sensible properties, as an introduction to the Aerosol Robotic Network (AERONET) results presented in Sect. 2.

\subsection{The solar flux-AOD technique and results}

The solar flux-AOD technique (Bergstrom et al., 2003, 2004, $2007,2009)$ uses a radiative transfer model to solve for the spectrum of aerosol single scattering albedo (SSA, the ratio of scattering to extinction) that provides the best match between measured and calculated spectra of atmospheric absorption of solar radiation. The measured absorption spectrum is obtained as the difference of net flux spectra measured at the top and bottom of an atmospheric aerosol layer by Solar Spectral Flux Radiometer (SSFR, Pilewskie et al., 2000, 2003). (A related technique uses flux measurements only at layer bottom e.g., Redemann et al., 2006.) The calculated absorption spectrum uses the layer AOD spectrum, obtained as the difference between AOD spectra measured at layer bottom and top by an Ames Airborne Tracking Sunphotometer (AATS, Matsumoto et al., 1987, Russell et al., 2005, 2007). The technique also provides the layer's aerosol absorption optical depth (AAOD) spectrum, obtained as

$\operatorname{AAOD}(\lambda)=[1-\operatorname{SSA}(\lambda)] \operatorname{AOD}(\lambda)$,

where $\lambda$ is wavelength. The technique is applied in conditions where little or no clouds are present to affect the solar flux measurements.
Recently Bergstrom et al. (2007) showed that spectra of aerosol SSA and AAOD obtained by the solar flux-AOD technique in different regions of the world varied significantly from region to region, in ways that could be ascribed to regional aerosol composition. Figure 1 summarizes the Bergstrom et al. (2007) results, and Table 1 summarizes locations and other characteristics of the campaigns in which the results were obtained.

SSA spectra obtained by the solar flux-AOD technique (Fig. 1 top left) have several desirable features:

1. They are obtained from direct measurements of radiant absorption and AOD.

2. Results describe the layer aerosol in its ambient state (without loss of large or small particles or condensed volatiles like water, organics, and nitrates).

3. Results cover a wide wavelength range, from near-UV, across the visible, and into the near-IR.

4. This wavelength range includes all or most aerosolmeasurement wavelengths of many spaceborne and airborne sensors (e.g., OMI, MISR, MODIS, CALIPSO, HSRL, Glory APS, RSP, POLDER).

5. The radiative calculations use an albedo spectrum for the surface-plus-atmosphere below the aircraft obtained directly from SSFR-measured upwelling and downwelling flux.

6. Use of the net flux difference between two altitudes to obtain the intervening absorption greatly reduces sensitivity to absorbing gases above and below the intervening layer, as well as to aerosol scattering asymmetry factor.

The difference in SSA spectral shapes and magnitudes from region to region in Fig. 1 (top left frame) is striking. So 

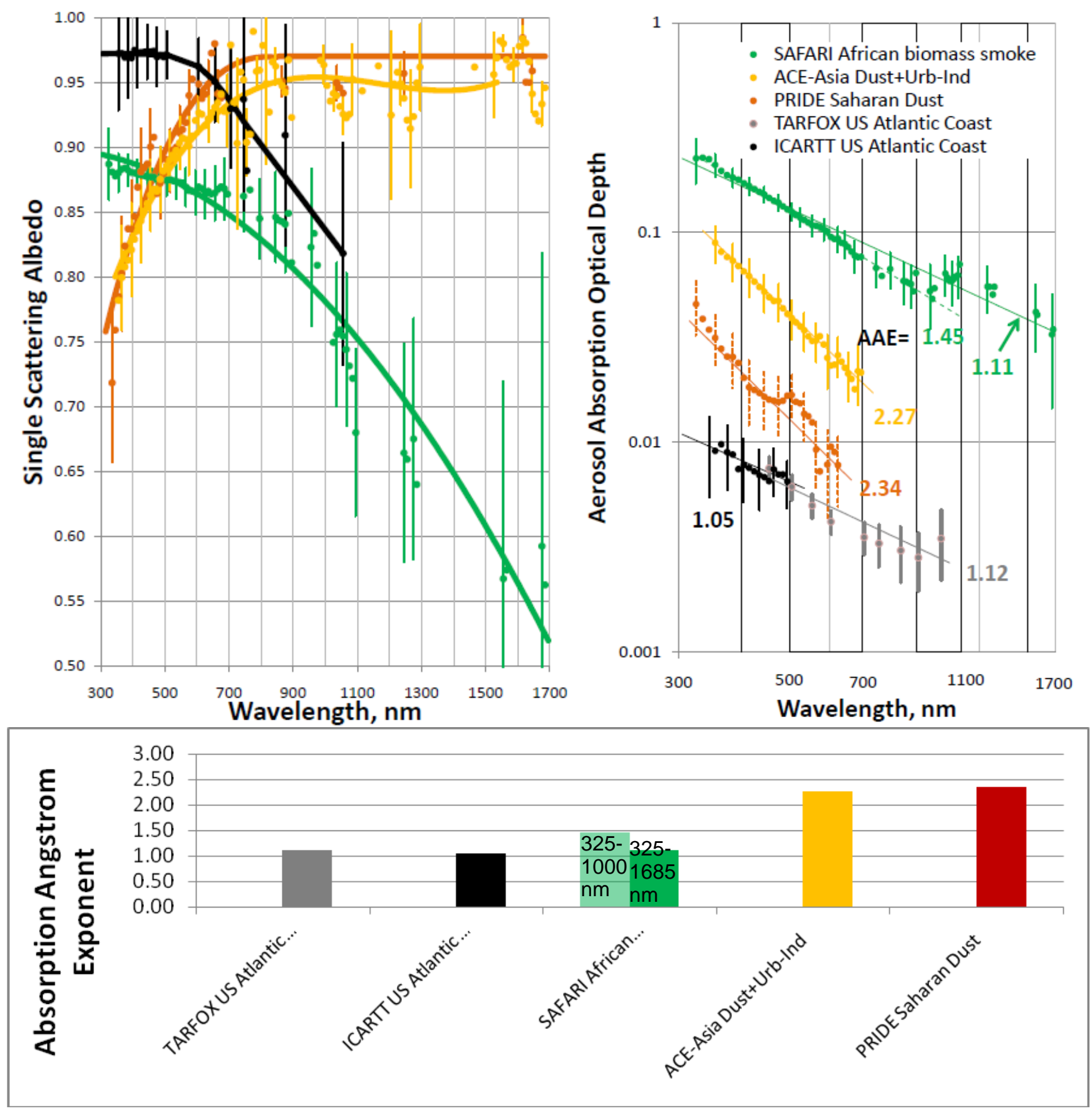

Fig. 1. Top: Spectra of Single Scattering Albedo (SSA) derived by the solar flux-AOD technique, reproduced from Bergstrom et al. (2007), with corresponding Aerosol Absorption Optical Depth (AAOD) spectra. (See Appendix for experiment acronyms.) The TARFOX absorption results are from laboratory analysis of collected aerosol samples, since SSFR did not fly in TARFOX. Bottom: Absorption Angstrom Exponent (AAE) values for the AAOD spectra above. The two AAE values for SAFARI are for different wavelength ranges (1.45 for $325-1000 \mathrm{~nm}, 1.11$ for $325-1685 \mathrm{~nm})$. 


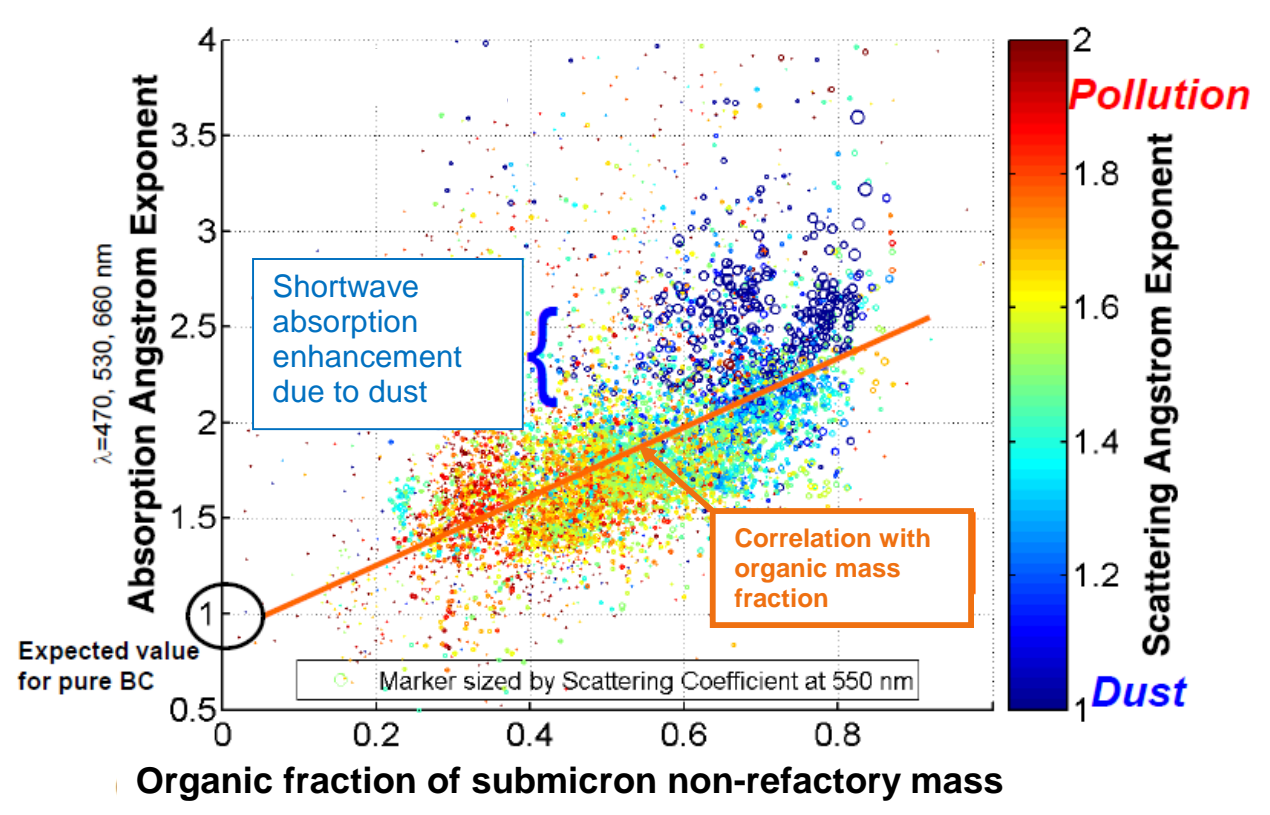

Fig. 2. Scatter plot of AAE vs. organic fraction of submicron non-refractory aerosol mass, color coded by scattering Angstrom exponent. Results are from in situ measurements of aerosols by absorption photometer, nephelometer, and aerosol mass spectrometer on the C-130 mostly over Central Mexico during MILAGRO in March 2006. (Shinozuka et al., 2008, 2009; DeCarlo et al., 2008; see Appendix for acronyms.) AAE and SAE are for total particles observed behind the aircraft inlet (i.e., not submicron aerosol).

is the change in coalbedo ( 1 minus SSA) over a relatively short wavelength range for some of the spectra. For example, PRIDE coalbedo changes from $\sim 0.24$ to $\sim 0.04$ (a factor of 6) between 315 and $700 \mathrm{~nm}$.

Figure 1 (top right frame) shows the spectra of AAOD corresponding to the SSA spectra in the top left frame, with the addition of TARFOX (US mid-Atlantic coast, urbanindustrial aerosol). (The TARFOX absorption results are from laboratory analysis of collected aerosol samples, since SSFR did not fly in TARFOX.) Another striking feature of Fig. 1 is that the very different shapes of SSA spectra in the top left frame all convert to AAOD spectra that can be fitted, to first approximation, by straight lines on the log-log plot. (We discuss departures from the straight-line fits later.) These fits are power laws, given by

$\mathrm{AAOD}=\mathrm{K} \lambda^{-\mathrm{AAE}}$,

where AAE is Absorption Angstrom Exponent. What distinguishes the AAOD spectra in Fig. 1 from each other is their slopes, i.e., their AAE values. The two experiments conducted in summer off the US East coast, TARFOX and ICARTT, have AAE close to 1. This is the theoretical AAE value for black carbon (Bergstrom, 1973; Bohren and Huffman, 1983), suggesting that aerosol absorption for this location and season is dominated by black carbon (a potential source of which is diesel exhaust). The next steeper slope, $\mathrm{AAE}=1.45$ (for wavelengths 325 to $1000 \mathrm{~nm}$ ), is for biomass burning aerosols in southern Africa. And the steepest slopes, $\mathrm{AAE}=2.27$ and 2.34, are for aerosols containing mineral dust, with the lesser of the two, 2.27, being for a mix of Asian dust and pollution. Figure 1 (bottom frame) shows AAE results from the five experiments.

\subsection{Airborne in situ measurements of composition, ab- sorption, and scattering}

Figure 2 shows measurements made on the C-130 aircraft in MILAGRO (Shinozuka et al., 2009; DeCarlo et al., 2008) that show similar behavior to that in Fig. 1, even though they were made entirely independently of the Fig. 1 results. The horizontal axis in Fig. 2 is the organic fraction of submicron non-refractory aerosol mass. Here "non-refractory" follows the empirical definition of Shinozuka et al. (2009), i.e., consisting of those species that evaporate in a few seconds under high vacuum at $600 \mathrm{C}$; it includes essentially all the organic species and most sulfates and nitrates, including their ammonium salts. The vertical axis is AAE calculated as a best fit of Eq. (2) to in situ aerosol absorption measurements at wavelengths 470,530 , and $660 \mathrm{~nm}$ (i.e., one straight line fitted to three data points in log-log coordinates). The color code for data points in Fig. 2 is scattering Angstrom exponent (SAE, $=-\Delta \ln \sigma / \Delta \ln \lambda$, where $\sigma$ is scattering coefficient), which relates inversely to particle size. AAE and SAE are for total particles observed behind the aircraft inlet (i.e., not submicron aerosol). Dark blue points indicate the smallest SAE values (hence the largest size), indicative of the presence of dust in this experiment. (See Fast et al., 2007 and Aiken et al., 2009 for descriptions of likely dust sources near Mexico 

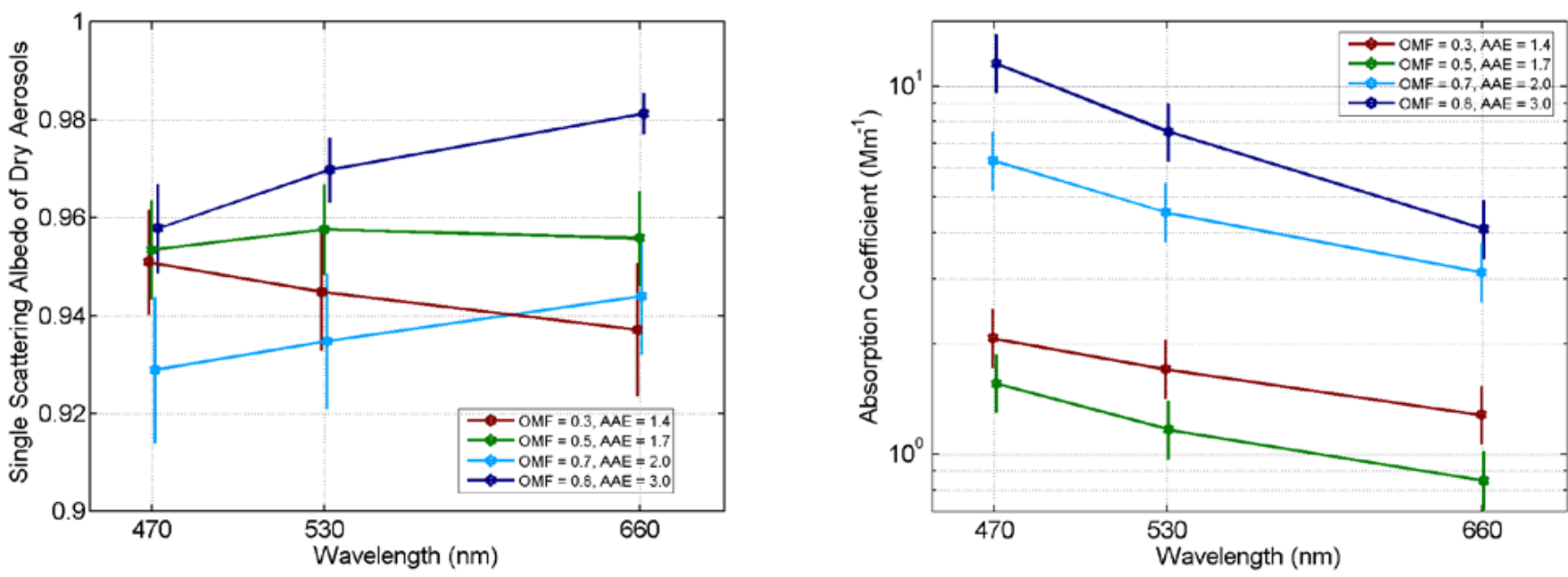

Fig. 3. Representative spectra of SSA and absorption coefficient for selected OMF and AAE values in Fig. 2. Error bars are from Shinozuka et al. (2009).

City, which include wind-blown bare soil, re-suspension by vehicles, a cement plant, and a limestone quarry.) If the dark blue points are excluded, the remaining points are described fairly well by the straight line shown. Note that the line has intercept $\mathrm{AAE}=1$, the value for pure black carbon. (The rarity of data points with $\mathrm{AAE}=1$ is consistent with the electron microscope results of Adachi and Busek (2008), which showed that most Mexico City particles containing black carbon were coated with organic matter and sulfates.) Thus, the data in Fig. 2 show that:

- When neither dust nor organics are present (i.e., organic fraction $=0$ and dark blue points excluded), $\mathrm{AAE}=1$, indicating black carbon is the dominant absorber;

- When dust is absent (dark blue points excluded), increasing organic fraction is accompanied by increasing AAE;

- For a given organic fraction, the presence of dust increases AAE still more.

It should be noted that some of the trend in Fig. 2 of AAE increase with OMF is likely due to different mixing of an urban (lower OMF, lower AAE) and biomass burning source (higher OMF, higher AAE). This source mixing does not change the observations given above. Although the wavelength range of the Fig. 2 results is limited $(\lambda=470,530$, $660 \mathrm{~nm})$ compared to Figure $1(\sim 325-1670 \mathrm{~nm})$, the similarity of these Fig. 2 general results to those discussed in connection with Figure 1 is noteworthy. Also noteworthy is the great difference in techniques used to generate the two figures: Fig. 1 used radiometric measurements (solar flux and AOD), and Fig. 2 used in situ measurements by nephelometer, absorption photometer, and aerosol mass spectrometer. Even the experiment locations differ: Fig. 1 comes from the
US Atlantic coast, Caribbean, East China Sea, and South Africa, whereas Fig. 2 comes from Central Mexico and the Gulf of Mexico (see Shinozuka et al. (2009) for related discussion).

Figure 3 shows another aspect of the recent MILAGRO $\mathrm{C}-130$ results that is consonant with the flux-AOD results: although the SSA spectra (left frame) vary considerably in slope and curvature, the corresponding absorption coefficient spectra (right frame) are to first order all power laws (i.e., nearly straight lines on the log-log plot) with negative slope, and increasing Organic Mass Fraction (OMF) yields larger slopes (AAE values). The slight curvature of the absorption coefficient spectra in Fig. 3 (right frame), characteristic of organics, is discussed further in Section 1.3. Note also that the SSA spectra in Fig. 3 (left frame) change slope, $\Delta \mathrm{SSA} / \Delta \lambda$, from negative to positive as OMF increases from 0.3 to 0.7 . This also is discussed further in Sects. 1.3 and 2.

\subsection{Additional in situ field and laboratory measure- ments}

The results in Figs. 1-3 are also consistent with several previous aerosol absorption results surveyed by Bergstrom et al. (2007). These include both the laboratory studies of Kirchstetter et al. (2004) and the field studies of Clarke et al. (2007), Roden et al. (2006), Sierau et al. (2006), Virkkula et al. (2006), and Schnaiter et al. (2006). These studies show that not only is AAE for organic species (sometimes called brown carbon) larger than for black carbon (e.g., Bond, 2001; Kirchstetter et al., 2004; Schnaiter et al., 2003), AAE for organic species can depend on wavelength (increasing for decreasing wavelength), whereas it is independent of wavelength for black carbon. The dependence of AAE on wavelength can be seen in Fig. 1 for the SAFARI case: note that AAE is 1.45 over the range $325-1000 \mathrm{~nm}$, but 1.11 over 
the range $325-1685 \mathrm{~nm}$. It is also evident in Fig. 3 (right frame), increasingly so for increasing organic mass fraction. Taking into account all the above and additional references, Bergstrom et al. (2007) conclude that AAE can be as large as 6 , and they show some measurements of $\mathrm{AAE}<1$, notably for Houston during GoMACCS in 2006 (Bates et al., 2008; Massoli et al., 2008). The GoMACCS measurements of $\mathrm{AAE}<1$ are from thousands of shipborne scattering and absorption measurements that yielded a distribution ranging from AAE $\sim 0.3$ to 3 with median values of $\sim 0.84,0.91, \&$ 1.07 for wavelength pairs 530 and 660, 467 and 660, and 467 and $530 \mathrm{~nm}$, respectively. Gyawali, et al. (2009) show that values of $\mathrm{AAE}<1$ (and indeed $>1$ ) can result from black carbon coated with either absorbing or nonabsorbing material, a point explored further by the calculations of Lack and Cappa (2010).

Other recent references showing large values of AAE for organic species include McMeeking (2008), McMeeking et al. (2008), Lewis et al. (2008), Barnard et al. (2008), Sandradewi et al. (2008), Martins et al. (2009), and Yang et al. (2009). Sandradewi et al. (2008) used the AAE difference between $\mathrm{BC}$ and organics to determine the relative contributions of traffic and wood burning to the carbonaceous mass of particulate matter in an Alpine valley town. McMeeking's work showed that the AAE values depended strongly on modified combustion efficiency (MCE), a measure of fire combustion conditions (flaming vs. smoldering). This dependence, coupled with the above-mentioned dependence of $\mathrm{AAE}$ on the proportion of black carbon vs. organic species in aerosols, produced a strong dependence of AAE on MCE. For example, as MCE increased from 0.8 to 1.0 (corresponding to the change from smoldering to flaming pine needles), AAE decreased from 4.6 to $\sim 1$. Simultaneously, the ratio of elemental carbon to total carbon increased from $\sim 0$ to $\sim 0.5$. These results offer the promise of using remote measurements of AAE (ideally combined with other remotely sensed variables) to determine whether a particular biomass smoke layer resulted from flaming or smoldering combustion. Yang et al. (2009) also apportioned the absorption by aerosols in China to black carbon, brown carbon, and dust, attributing the high AAE values of dust to the presence of ferric oxides.

Three recent papers (Barnard et al., 2008; Marley et al., 2009; Corr et al., 2009) report enhanced absorption in the $300-500 \mathrm{~nm}$ wavelength range for aerosols in the Mexico City area. Corr et al. (2009) find SSA having little or no wavelength dependence for the wavelength pair 332 and $368 \mathrm{~nm}$, with values varying between $\sim 0.70$ and $\sim 0.86$. Barnard et al. (2008) also find SSA having little or no wavelength dependence between $\sim 300$ and $\sim 400 \mathrm{~nm}$, with values varying between $\sim 0.67$ and $\sim 0.78$. Barnard et al. (2008) report a steep increase in SSA between $\sim 400$ and $500 \mathrm{~nm}$, with $\operatorname{SSA}(500 \mathrm{~nm}) \sim 0.87$ to 0.95 , and decreasing SSA from 500 to $870 \mathrm{~nm}$, with $\operatorname{SSA}(870 \mathrm{~nm}) \sim 0.81$ to $\sim 0.93$. They attribute the enhanced absorption for $\lambda<400 \mathrm{~nm}$ to organic matter, as do Marley et al. (2009). (Strong UV absorp- tion by very many organic species is documented by Jacobson (1998), although not expressed as $\operatorname{SSA}(\lambda)$.) The positive $\Delta \mathrm{SSA} / \Delta \lambda$ found by Barnard et al. between $\lambda=400$ and $500 \mathrm{~nm}$ is similar to the positive $\Delta \mathrm{SSA} / \Delta \lambda$ shown in Fig. 3 (left frame) for MILAGRO C-130 results with $\mathrm{OMF} \geq 0.5$, although the different measurement wavelengths used by the C-130 and Barnard et al. prevent exact comparisons.

AAOD spectra calculated from the SSA and AOD values in Barnard et al. (2008) do not follow a power law with near-constant AAE over their wavelength range (300$870 \mathrm{~nm}$ ), and hence Barnard et al. find AAE values that are strongly dependent on wavelength pair (3.2 to 5.1 for 300$500 \mathrm{~nm} ; 1.9$ to 2.6 for $300-870 \mathrm{~nm})$. In contrast, Marley et al. (2009) find a different, and relatively restricted, range of AAE (0.63 to 1.5 including both 2003 and 2006 field campaigns) over the wavelength range 370 to $950 \mathrm{~nm}$. Bergstrom et al. (2009) report wavelength-dependent AAE from Solar flux-AOD analyses of airborne measurements in the Mexico City area and over the Gulf of Mexico. Hence, further research is needed to understand the differences among these Mexico City results, as well as the differences between the Mexico City results and those in Fig. 1, which are for cases relatively far from urban areas.

\subsection{Recent efforts to derive information on aerosol com- position from AERONET retrieved complex refrac- tive index}

The ground-based AERONET network of Sun-sky radiometers (Holben et al., 2001) produces measurements of solar direct-beam transmission and sky radiance that are inverted to yield aerosol column size distributions and complex refractive indices at four wavelengths: 440, 670, 870, and 1020 nm (e.g., Dubovik \& King, 2000; Dubovik et al., 2000). Recently, Schuster et al. $(2005,2009)$ have demonstrated the use of AERONET-retrieved complex refractive index to derive information about both aerosol black carbon content and water uptake. In the following section we present results of a different but related approach that assesses the usefulness of AERONET-retrieved SSA, AAOD, and AAE as indicators of aerosol composition, including black carbon, organic matter, and mineral dust.

\section{AAOD spectra and AAE values from AERONET measurements of key aerosol types}

Dubovik et al. (2002a) present representative aerosol size distributions and SSA spectra derived from 8 years of measurements by AERONET Sun-sky radiometers (Holben et al., 2001) at locations around the world where key aerosol types tend to prevail, especially during particular seasons. The Dubovik et al. (2002a) results were derived using the AERONET Version 1 retrieval, with cases restricted to large AOD, so that results for SSA differ negligibly from results 
Table 2. Color coding of sites/periods in Fig. 4, with designations by Dubovik et al. (2002a). SSA retrievals were restricted to cases with $\operatorname{AOD}(440 \mathrm{~nm})>0.4$ for Urban-industrial, mixed, and biomass burning aerosols, and $\mathrm{AOD}(1020 \mathrm{~nm})>0.3 \mathrm{and} \mathrm{EAE}(440,780 \mathrm{~nm})<0.6$ for desert dust. See also footnotes for further restrictions and their effects.

\begin{tabular}{llll}
\hline Color & Site & Period & Designation \\
\hline Black & Goddard Space Flight Center, Greenbelt, & Jun-Sep 1993-2000 & Urban-industrial \\
& MD & & $N^{*}$ \\
Black & Creteil/Paris, France & Jun-Sep 1999 & Urban-industrial \\
Black & Mexico City & All months 1999-2000 & Urban-industrial \\
Black & Maldives (INDOEX) & Jan-Apr 1999-2000 & Mixed † \\
Green & Amazonian forest & & Biomass burning \\
& - Brazil & Aug-Oct 1993-1994 & \\
Green & - Bolivia & Aug-Oct 1998-1999 & \\
Green & African savanna, Zambia & Aug-Oct 1993-1995 & Biomass burning \\
Green & Boreal forest, US and Canada & Aug-Nov 1995-2000 & Biomass burning \\
Red-brown & Bahrain-Persian Gulf & Jun-Sep 1994-1998 & Biomass burning \\
Red-brown & Solar Village, Saudi Arabia & All months 1998-2000 & Desert dust \\
Red-brown & Cape Verde & All months 1998-2000 & Desert dust \\
\hline
\end{tabular}

* Number of SSA retrievals

$\dagger$ The restriction of SSA retrievals to conditions with $\operatorname{AOD}(440 \mathrm{~nm})>0.4$ effectively restricts Maldives retrievals to conditions of pollution transport from India.

using the later-developed (and currently used) AERONET Version 2 retrieval. (Specifically, cases shown in Fig. 1 of Dubovik et al. (2002a) were restricted to $\operatorname{AOD}(440 \mathrm{~nm})>0.7$, and SSA results in their Table 2 were restricted as described in our Table 2. Version 1 does not account for nonsphericity (introduced later by Dubovik et al., 2002b, 2006). However, as discussed by Dubovik et al. (2000, 2002a) particle nonsphericity does not affect SSA retrieval.)

Although AAOD results are not presented by Dubovik et al. (2002a), results in their Table 2 for SSA spectra and average AOD values at a particular wavelength (440 or $1020 \mathrm{~nm}$ ), together with their Fig. 1 results for typical extinction Angstrom exponents, allow calculation of representative AAOD spectra at those locations. Figure 4 shows results of such calculations, along with the corresponding SSA spectra from Table 2 of Dubovik et al. (2002a). We have color-coded the results in Fig. 4 according to the aerosol type designations of Dubovik et al. (2002a), which apply to SSA retrievals restricted at some sites to certain months, as detailed in our Table 2.

Noteworthy features of Fig. 4, which describe the full aerosol vertical column, are:

- The SSA spectra for AERONET locations dominated by desert dust (red-brown curves in Fig. 4) increase with increasing wavelength, similar to the Bergstrom et al. (2007) SSA spectra for dust-containing aerosols (PRIDE and ACE-Asia, Fig. 1).

- The SSA spectra for AERONET locations dominated by urban-industrial and biomass-burning aerosols (black and green curves in Fig. 4) decrease with increasing wavelength, similar to the Bergstrom et al. (2007) SSA spectra for such aerosols (ICARTT and SAFARI, top row of Fig. 1).

- Despite the variety of AERONET-derived SSA spectral shapes in Fig. 4, they all convert to AAOD spectra (top right frame) that can be fitted to first order by straight lines in the log-log plot - i.e., by power laws, as in Bergstrom et al. (2007; Fig. 1 of this paper).

- The AERONET desert dust locations (red-brown curves and bars in Fig. 4) clearly have the steepest AAOD slopes (i.e., largest AAE values), consistent with both the Bergstrom et al. (2007) results in Fig. 1 and the in situ MILAGRO C-130 results in Fig. 2.

- Both the urban-industrial and biomass-burning AERONET sites (black and green bars in the bottom frame of Fig. 4) show some wavelength dependence of AAE (increasing for decreasing wavelength), which, as noted above, Bergstrom et al. (2007) have stated is characteristic of organic species.

Although the distinction in AAOD slopes between urbanindustrial (black curves) and biomass-burning (green curves) sites in Fig. 4's upper right frame is not as clear as might be inferred from the Bergstrom and MILAGRO C-130 results in Figs. 1 and 2, the bars in Fig. 4's bottom frame do show that the green group collectively has larger average AAE than the black group. Moreover, locations within the black group may have aerosols containing organic species, mineral dust, 

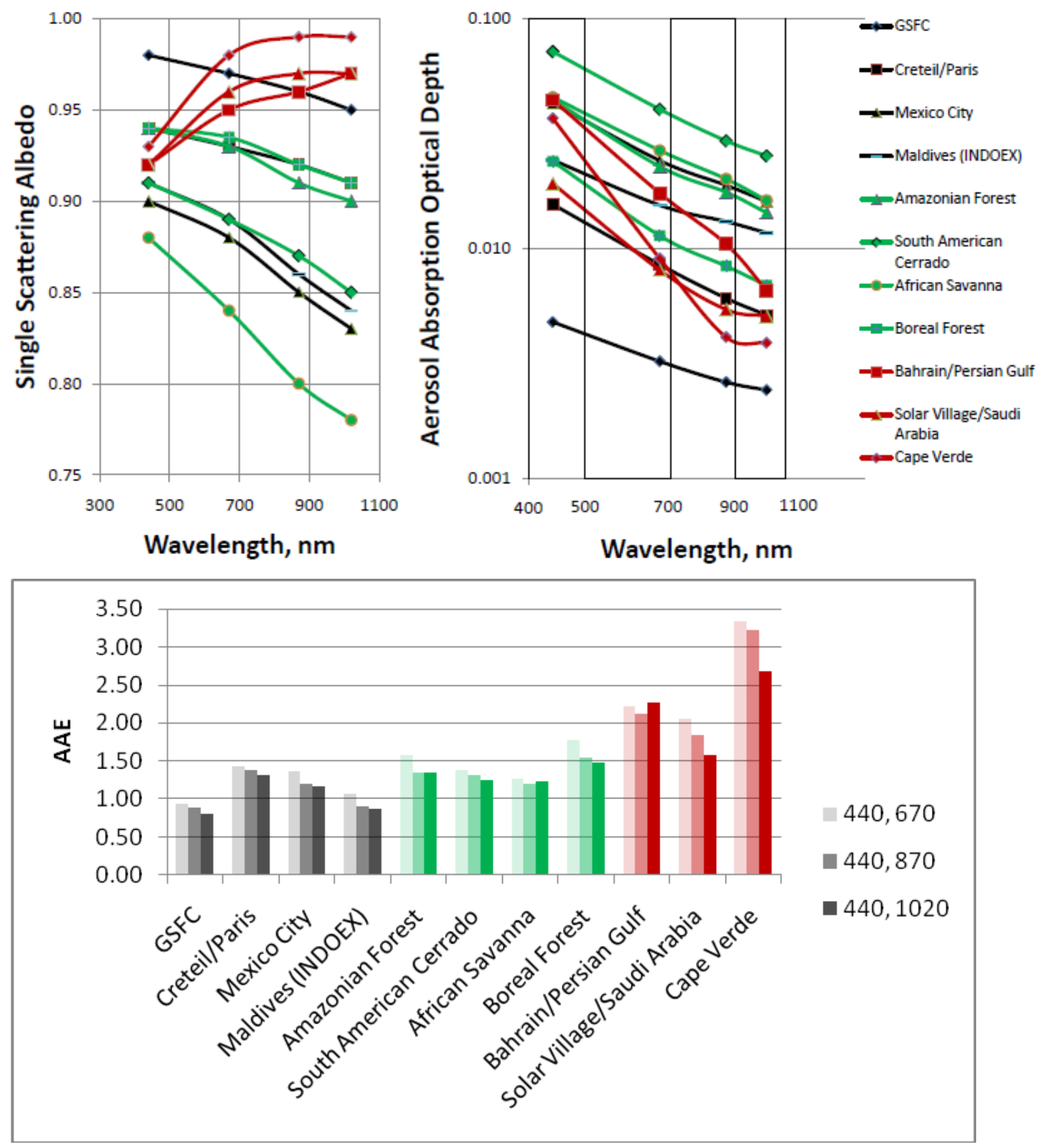

Fig. 4. Top: Spectra of AERONET-derived Single Scattering Albedo (SSA) from Dubovik et al. (2002a), with corresponding Aerosol Absorption Optical Depth (AAOD) spectra. Black: Urban/Industrial or Mixed; Green: Biomass Burning; Red-Brown: Desert Dust. Bottom: Absorption Angstrom Exponent (AAE) values for the AAOD spectra above. Shading for each location indicates wavelength pair (in nm) for AAE calculation. GSFC=Goddard Space Flight Center, Greenbelt, MD, USA. 
or both in addition to black carbon, especially considering that the AERONET results describe the full vertical column, which can contain several aerosol layers of different type. Indeed, Fig. 2 shows that Mexico City aerosols typically contain organic species, dust, or both, and Salcedo et al. (2006), DeCarlo et al. (2008), and Aiken et al. (2009) document that organic species consistently contribute about half the submicron mass in Mexico City aerosols, which represents a larger fraction of organic species than at locations in the US East Coast (Zhang et al., 2007). The larger AERONET AAE values for Mexico City as compared to Goddard Space Flight Center (GSFC, bottom row, Fig. 4) are thus consistent with the Bergstrom results in Fig. 1 and the MILAGRO C-130 in situ results in Fig. 2. (This follows from GSFC's location near the US Atlantic coast, site of TARFOX and ICARTT, and the Bergstrom et al. AAE values from those experiments (AAE $=1.12$ and 1.05, smallest of all the Bergstrom AAE results, suggesting black carbon dominates aerosol absorption there).

The AERONET AAE values $<1$ in Fig. 4 , bottom frame (GSFC and Maldives) are consistent with the shipborne $\mathrm{AAE}<1$ results for Houston during GoMACCS cited by Bergstrom et al. (2007, see above) and also the Gyawali et al. (2009) results showing that black carbon with either absorbing or nonabsorbing coatings can produce $\mathrm{AAE}<1$. Moreover, the AERONET GSFC AAE values (0.81 to 0.94, depending on wavelength pair) are close to 1 , and the differences from 1 may simply reflect the accuracy of the technique. The Maldives AERONET AAE values (0.87 to 1.07, depending on wavelength pair) are closer still to 1 . Another consideration is that the AERONET results in Fig. 4 are based on the location-averaged results in Dubovik et al. (2002a), rather than results from individual AERONET retrievals.

The negative slopes, $d \mathrm{SSA} / d \lambda<0$, for AERONET biomass burning locations in Fig. 4 (green curves, left frame) are consistent with the negative slope for SAFARI biomass burning smoke in Fig. 1 (green curve, left frame) from the flux-AOD technique. However, because biomass smokes contain organics, this raises the question of consistency with the positive slope, $d \mathrm{SSA} / d \lambda>0$, found by Barnard et al. (2008) for Mexico City and attributed to organics. We speculate that at least part of the explanation is the relative amounts of $\mathrm{BC}$ and organics in wildfire smokes and in the Mexico City aerosols observed by Barnard et al. Indeed, Fig. 3 (left frame) shows that, for the Mexico aerosols sampled by the C-130 in MILAGRO, increasing OMF causes the slope, $d \mathrm{SSA} / d \lambda$, to change from negative to positive. As noted above, Salcedo et al. (2006), DeCarlo et al. (2008), and Aiken et al. (2009) found that organic species contributed about half the submicron mass in Mexico City aerosols, a larger fraction than at US East Coast locations (Zhang et al., 2007). We speculate that larger ratios of BC to organic matter in wildfire smokes could be responsible for the $\mathrm{BC}$ (with $\mathrm{dSSA} / \mathrm{d} \lambda<0$ ) outweighing the organic mat- ter (with $\mathrm{dSSA} / \mathrm{d} \lambda>0$ ), but this is clearly a subject for further research. Effects of aerosol mixtures and evolution on AERONET-retrieved SSA spectra are explored by Eck et al. (2005) for Asian and mid-Pacific aerosols.

A note on seasalt aerosols. Seasalt aerosols can be important at many coastal and oceanic sites, and indeed Dubovik et al. (2002a) include results from a 12th site, Lanai, HI (not shown in our Fig. 4 or Table 2), which they designate as oceanic (i.e., expected to be dominated by aerosols of maritime origin, with some influence of Asian dust and pollution in Spring - as later documented by Eck et al., 2005). We have excluded the Dubovik et al. (2002a) Lanai results from this paper because many studies of seasalt optical properties (e.g., Shettle and Fenn, 1979; WMO, 1983; Koepke et al., 1997; Hess et al., 1998; Tanre et al., 1999) indicate negligible absorption (hence undefined AAE) for the AERONET wavelength range $(440-1020 \mathrm{~nm})$. Indeed, the AERONETretrieved SSA values at Lanai are within a standard deviation of 1.00 (specifically, $0.98,0.97,0.97,0.97 \pm 0.03$ at 440,670 , 870 , and $1020 \mathrm{~nm}$, where the 0.03 is the standard deviation of the 150 SSA retrievals at Lanai. Moreover, as pointed out by Dubovik et al. (2002a), the small AOD at Lanai (AOD $(440 \mathrm{~nm}$ ) usually less than 0.15 ) causes the AERONET retrieval uncertainty for aerosol absorption and SSA to be significantly larger than for the other sites, where SSA retrievals were restricted to cases with $\operatorname{AOD}(440 \mathrm{~nm}) \geq 0.4$. Thus, the technique emphasized in this paper, of using AAE as an indicator of aerosol composition (or even combining AAE and EAE, as in Sect. 3) is not applicable to pure seasalt aerosol, because of undefined AAE. Even in the case of seasalt mixed with enough absorbing material $(B C, O C$ or dust) to produce a well defined AAE, that AAE would be characteristic of the absorbing material, not seasalt. However, another approach, applicable to the optical data sets from AERONET and the other techniques described in this paper, would be to identify as seasalt aerosol those cases with $\mathrm{SSA} \cong 1$ and EAE small (hence particles large). As shown by Figure 1 and Table 1 of Dubovik et al. (2002a), another characteristic of the oceanic site Lanai is relatively small retrieved values of both real and imaginary refractive index. This is an example of information that could be used to identify seasalt in multidimensional clustering analyses, described further in the following section.

\section{Additional information from clustering analyses}

Ambiguities in aerosol composition or mixtures thereof, resulting from intermediate AAE values, can be reduced via cluster analyses that supplement AAE with other variables. For example, Fig. 5 shows that a scatter plot of AAE vs extinction Angstrom exponent (EAE, for wavelengths 440 and $870 \mathrm{~nm}$ ) for the 11 non-oceanic AERONET sites in Dubovik et al. (2002a) has points grouped in clusters. Such an analysis clearly shows the distinction between the aerosol types 


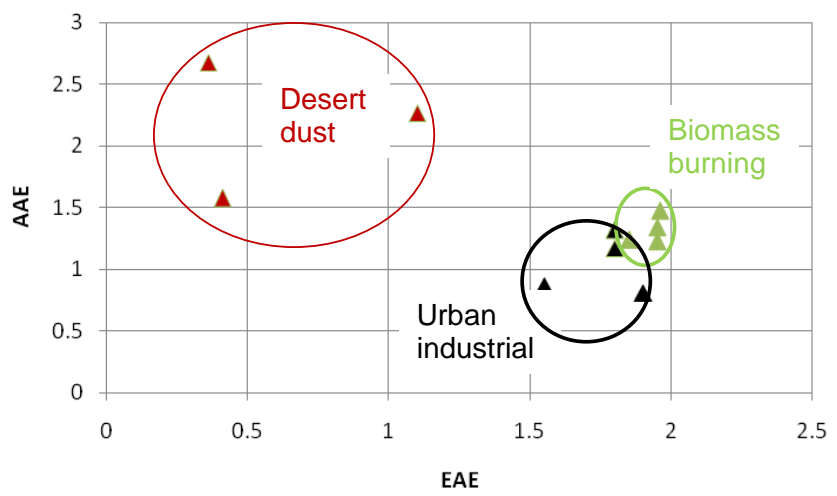

Fig. 5. Scatter plot of AERONET-derived AAE vs. EAE for the 11 non-oceanic sites in Dubovik et al. (2002a), showing the clustering by aerosol type that results.

at Solar Village/Saudi Arabia and at Boreal Forest, which have similar AAE values ( 1.4 to 1.6), but very different EAE values ( $\sim 0.4$ and 1.9 , respectively), reflecting the much larger particle sizes at the former site. This is consonant with the results in Fig. 2, which show that information on aerosol type can come not only from the wavelength dependence of absorption, but also from the size information in the wavelength dependence of scattering. Indeed, Clarke et al. (2007) have used this type of two-dimensional cluster analysis (plotting SAE vs AAE) to distinguish dust, biomass burning, and pollution plumes in airborne in situ data. They even find evidence of a separation between scrubbed coal-fired power plant plumes and regional strong urban pollution in AAESAE space, which they attribute to the combined presence of brown carbon and smaller particles in the power plant plumes. Yang et al. (2009) show an SAE vs AAE plot for their results for the EAST-AIRE field program near Beijing. They conclude that dust generally had SAE close to zero due to the large particle size, while its AAE was high but variable. Fresh chimney plumes were characterized by a nearunity AAE, which is expected for soot carbon. In comparison, coal pollution aerosols were much more variable in optical characteristics, likely due to formation of brown carbon and clay in addition to soot carbon.

In addition to differences in $\mathrm{AAE}, \mathrm{EAE}$, and $\mathrm{SAE}$, the slopes and shapes of SSA spectra in Figs. 1 and 4 show differences that correlate with aerosol type (e.g., dust SSA spectra have positive slope and negative curvature, whereas urbanindustrial and biomass smoke SSA spectra have negative slope). This suggests the value of combining several different types of remotely sensed information in multi-dimensional cluster analyses to derive the most information on aerosol type (e.g., to reduce the ambiguity resulting from the partial overlap of the biomass burning and urban-industrial clusters in Fig. 5). Indeed, Cattrall et al. (2005) have developed an objective cluster analysis technique that combines 4 different lidar-derived variables to classify aerosol type, using as a basis retrievals of aerosol properties at 26
AERONET sites. This technique has been applied both by Hostetler et al. (2008) to derive aerosol type from airborne High Spectral Resolution Lidar (HSRL) measurements, and by Reagan et al. (2004) to simulated spaceborne CALIOP measurements. In the HSRL algorithm, the input variables are 4 intensive parameters: extinction/backscatter ratio (sensitive to absorption), depolarization (shape), backscatter color ratio (size), and depolarization color ratio (nonspheri$\mathrm{cal} / \mathrm{spherical}$ size). The algorithm finds eight significant clusters, designated Biomass+urban, Urban + biomass, Urban (large), Urban biomass + large dust, Urban biomass + small dust, Dust + urban, Dust (large), and Pure dust.

Another successful application of clustering was by Omar et al. (2005) who used cluster analysis by partitioning (cf. Kaufman and Rousseeuw, 1990) to classify global atmospheric aerosols using the complete AERONET archive ( $>143000$ data records from $>250$ sites) as of December 2002. They used as input 26 AERONET-derived parameters (mean radius, width, and volume of 2 size modes, plus real and imaginary refractive index, SSA, asymmetry factor, and extinction/backscatter ratio, each at 4 wavelengths) and found six significant clusters of aerosol type, which varied in prevalence with season at each site. In addition, Levy et al. (2007) used cluster analysis to generate, from the AERONET data base, aerosol classes that now are used in the MODIS retrieval algorithm.

\section{Potential for improved spaceborne determination of aerosol composition or type}

Kaufman et al. (2002) and Yu et al. (2009) have shown that it is possible to retrieve useful information on aerosol type, and indeed to help distinguish natural from anthropogenic aerosols, by using the aerosol size information in MODISretrieved values of EAE. Here we point out the potential to improve this space-derived information on aerosol type, provided aerosol absorption wavelength dependence could be determined from space. In fact, as displayed in Table 3, the Glory Aerosol Polarimetry Sensor (APS; Mishchenko et al., 2007) aims to provide retrievals of multiwavelength singlescattering albedo (SSA) and aerosol optical depth (hence aerosol absorption optical depth (AAOD) and AAE), as well as shape and other aerosol properties. (Glory is scheduled for launch no earlier than 1 October 2010 http://www.nasa.gov/ missions/highlights/schedule.html.) The APS level-3 aerosol data products listed in Table 3 will be retrieved from APS measurements of the four Stokes parameters, I, Q, U, and V, describing the intensity and polarization state of the received radiation at wavelengths $410,443,555,670,865,910,1370$, 1610 , and $2250 \mathrm{~nm}$. The high accuracy, polarization diversity, and broad spectral range planned for APS are expected to yield the uncertainties listed in Table 3, which will be a significant step forward for space-based aerosol data products. 
Table 3. Glory Aerosol Polarimetry Sensor (APS) level-3 aerosol data products (adapted from Mishchenko et al., 2007).

\begin{tabular}{lll}
\hline Data product (fine and coarse modes) & Range & Uncertainty \\
\hline Column spectral* aerosol optical depth $^{*}$ & $0-5$ & 0.02 over ocean 0.04 over land \\
Aerosol effective radius & $0.05-5 \mu \mathrm{m}$ & $10 \%$ \\
Effective variance of aerosol size distribution & $0-3$ & $40 \%$ \\
Aerosol spectral* real refractive index & $1.3-1.7$ & 0.02 \\
Aerosol spectral* single-scattering albedo & $0-1$ & 0.03 \\
Aerosol morphology & Spherical aerosols, irreg- & N/A \\
& ular dust particles, soot \\
& clusters \\
\hline
\end{tabular}

*At least in three spectral channels; relative accuracy better where AOD is larger (typically 410-865 nm).

As shown by Figs. 1 and 4, the Glory APS-derived results for $\operatorname{AAOD}(\lambda)$ and $\mathrm{AAE}$ should of themselves contain improved information on aerosol composition. Combining APS-derived AAE with other APS-derived variables like EAE, shape, and real refractive index in clustering analyses like those described in the preceding section would provide even further information on aerosol composition and type. Information content could be further enhanced by using any available near-coincident OMI-derived AAOD values to extend the Glory AAOD results to shorter wavelengths (343$484 \mathrm{~nm}$ ), thus providing more overlap with the airborne solar flux-AOD results $(\sim 325-1670 \mathrm{~nm})$ and better coverage of the near UV, where absorption by organics and dust is often strongest (see Fig. 1). Further, adding CALIPSO data on aerosol layer height would reduce the ambiguity in aerosol absorption that would otherwise apply (e.g., Torres et al., 1998, 2005; Chowdhary et al., 2005; Waquet et al., 2009).

\section{Summary, conclusions and recommendation}

AAOD spectra calculated from the AERONET results of Dubovik et al. (2002a) at 11 sites representative of different aerosol types show that AAE values describing the full aerosol vertical column are strongly correlated with aerosol composition or type. In particular, we find AAE values near 1 (the theoretical value for black carbon) for AERONET-measured aerosol columns dominated by urbanindustrial aerosol, with larger AAE values for biomass burning aerosols, and the largest AAE values for Sahara dust aerosols. These results are consistent with, and extend, previous results from diverse air, ground, and laboratory studies using both radiometric and in situ techniques, which showed that the fractions of black carbon, organic species, and mineral dust in aerosols determine the wavelength dependence of absorption. The AERONET results reported here extend the previous results to a large, globally distributed data set describing the full vertical column of aerosols, which can contain layers of different aerosol types. The AERONET results represent a middle ground between passive downward- viewing measurements from space and the previous in situ and height-resolved results in that the AERONET results describe the full vertical column of aerosols (like passive downward-viewing measurements from space) while taking advantage of combined measurements of scattered light and direct-beam transmission (which passive downward-viewing measurements from space cannot).

Ambiguities in aerosol composition or mixtures thereof, resulting from intermediate $\mathrm{AAE}$ values, can be reduced via cluster analyses that supplement AAE with other variables, for example extinction Angstrom exponent (EAE), which is an indicator of particle size. Together with previous results, these results strengthen prospects for determination of aerosol composition from space, for example using the Glory Aerosol Polarimetry Sensor, which seeks to provide retrievals of multiwavelength SSA and AOD (hence AAOD and AAE), as well as shape and other aerosol properties. Multidimensional cluster analyses promise additional information content, for example by using the Ozone Monitoring Instrument to add AAOD in the near ultraviolet and CALIPSO aerosol layer heights to reduce height-absorption ambiguity.

Finally, we emphasize that the AERONET AAE results reported here are derived from a specific AERONET data set, namely the SSA and AOD values in Table 2 of Dubovik et al. (2002a) and the EAE values in Fig. 1 of that paper, all of which are from the AERONET Version 1 retrieval (with the restrictions described in our Section 2 and Table 2). Although that data set represents hundreds of retrievals at eleven sites (or groups of sites-see our Table 2) widely distributed around the globe, much larger AERONET data sets, derived using the Version 2 retrieval, are available at http: //aeronet.gsfc.nasa.gov/cgi-bin/webtool_opera_v2_inv. We recommend further investigation of relationships between AERONET-derived AAE and aerosol type using the larger Version 2 data set, with particular attention to remaining questions regarding aerosols of mixed type, as mentioned in Sects. 1.3 and 2. 
Appendix A

Acronyms

AAOD

AATS

ACE

AERONET

AOD

APS

CALIOP

CALIPSO

EAE

EAST-AIRE

GoMACCS

GSFC

HSRL

ICARTT

INDOEX

INTEX or

INTEX-NA

INTEX-A or -

B

IR

MCE

MISR

MODIS

MILAGRO

NIR

OMF

OMI

POLDER

PRIDE

RSP

SAE

SAFARI

SSA

SSFR
Absorption Angstrom Exponent

Aerosol Absorption Optical Depth

Ames Airborne Tracking Sunpho-

tometer

Aerosol Characterization Experi-

ment, or

Aerosol/Cloud/Ecosystems

(Decadal Survey Mission)

Aerosol Robotic Network

Aerosol Optical Depth

Aerosol Polarimetry Sensor

Cloud-Aerosol Lidar with Orthogonal Polarization

Cloud-Aerosol Lidar and Infrared

Pathfinder Satellite Observations

Extinction Angstrom Exponent

East Asian Study of Tropospheric

Aerosols: an International Regional Experiment

Gulf of Mexico Atmospheric Composition and Climate Study

Goddard Space Flight Center

High Spectral Resolution Lidar

International Consortium for Atmospheric Research on Transport and Transformation

Indian Ocean Experiment

Intercontinental Chemical Trans-

port Experiment-North America

Phase A or B of INTEX-NA

Infrared

Modified Combustion Efficiency

Multi-angle Imaging SpectroRadiometer

Moderate-resolution Imaging

Spectroradiometer

Megacity Initiative: Local and

Global Research Observations

Near Infra-Red

Organic Mass Fraction

Ozone Monitoring Instrument

Polarization and Directionality of

Earth Radiances

Puerto Rico Dust Experiment

Research Scanning Polarimeter

Scattering Angstrom exponent

Southern Africa Regional Science

Initiative

Single Scattering Albedo

Solar Spectral Flux Radiometer
TARFOX Tropospheric Aerosol Radiative

Forcing Observational Experiment

UV

Ultraviolet

Acknowledgements. PBR, RWB, JML, JR, and AS were supported by the NASA Radiation Science Program. ADC and YS were supported by NSF grant number ATM05-11521. PFD and JLJ were supported by NASA NNX08AD39G, NSF/UCAR S05-39607, and NSF-ATM-0513116. We appreciate helpful discussions with Brent Holben and Lorraine Remer on AERONET measurements, with Omar Torres on OMI future measurements and with Brian Cairns on Glory APS measurements, as well as internal reviews by Robert Chatfield and Laura Iraci.

Edited by: T. Kirchstetter

\section{References}

Adachi, K. and Buseck, P. R.: Internally mixed soot, sulfates, and organic matter in aerosol particles from Mexico City, Atmos. Chem. Phys., 8, 6469-6481, 2008

Aiken, A. C., Salcedo, D., Cubison, M. J., Huffman, J. A., DeCarlo, P. F., Ulbrich, I. M., Docherty, K. S., Sueper, D., Kimmel, J. R., Worsnop, D. R., Trimborn, A., Northway, M., Stone, E. A., Schauer, J. J., Volkamer, R. M., Fortner, E., de Foy, B., Wang, J., Laskin, A., Shutthanandan, V., Zheng, J., Zhang, R., Gaffney, J., Marley, N. A., Paredes-Miranda, G., Arnott, W. P., Molina, L. T., Sosa, G., and Jimenez, J. L.: Mexico City aerosol analysis during MILAGRO using high resolution aerosol mass spectrometry at the urban supersite (T0) Part 1: Fine particle composition and organic source apportionment, Atmos. Chem. Phys., 9, 66336653, 2009, http://www.atmos-chem-phys.net/9/6633/2009/.

Barnard, J. C., Volkamer, R., and Kassianov, E. I.: Estimation of the mass absorption cross section of the organic carbon component of aerosols in the Mexico City Metropolitan Area, Atmos. Chem. Phys., 8, 6665-6679, 2008,

http://www.atmos-chem-phys.net/8/6665/2008/.

Bates, T. S., Quinn, P. K., Coffman, D., et al.: Boundary layer aerosol chemistry during TexAQS/GoMACCS 2006: Insights into aerosol sources and transformation processes, J. Geophys. Res., 113, D00F01, doi:10.1029/2008JD010023, 2008.

Bergstrom, R. W.: Extinction and Absorption Coefficients of the Atmospheric Aerosol as a Function of Particle Size, Contr. Atmos. Phys., 46, 223-234, 1973.

Bergstrom, R. W., Russell, P. B., and Hignett, P.: Wavelength dependence of the absorption of black carbon particles: Predictions and results from the TARFOX experiment and implications for the aerosol single scattering albedo, J. Atmos. Sci., 59, 568-578, 2002.

Bergstrom, R. W., Pilewskie, P., Schmid, B., and Russell, P. B.: Estimates of the spectral aerosol single scattering albedo and aerosol radiative effects during SAFARI 2000, J. Geophys. Res., 108(D13), 8474, doi:10.1029/2002JD002435, 2003.

Bergstrom, R. W., Pilewskie, P., Pommier, J., Rabbette, M., Russell, P. B., Schmid, B., Redemann, J., Higurashi, A., Nakajima, T., and Quinn, P. K.: Spectral absorption of solar radiation by aerosols during ACE-Asia, J. Geophys. Res., 109, D19S15, doi:10.1029/2003JD004467, 2004. 
Bergstrom, R. W., Pilewskie, P., Russell, P. B., Redemann, J., Bond, T. C., Quinn, P. K., and Sierau, B.: Spectral absorption properties of atmospheric aerosols, Atmos. Chem. Phys., 7, 5937-5943, 2007, http://www.atmos-chem-phys.net/7/5937/2007/.

Bergstrom, R. W., Schmidt, K. S., Coddington, O., Pilewskie, P., Guan, H., Livingston, J. M., Redemann, J., and Russell, P. B.: Aerosol spectral absorption in the Mexico City area: results from airborne measurements during MILAGRO/INTEX B, Atmos. Chem. Phys. Discuss., 9, 27543-27569, 2009, http://www.atmos-chem-phys-discuss.net/9/27543/2009/.

Bohren, C. F. and Huffman, D. R.: Absorption and scattering of light by small particles, John Wiley and Sons, New York, 530 pp., 1983.

Bond, T. C.: Spectral Dependence of Visible Light Absorption by Carbonaceous Particles Emitted from Coal Combustion, Geophys. Res. Lett., 28(21), 4075-4078, 2001.

Cattrall, C., Reagan, J. A., Thome, K., and Dubovik, O.: Variability of aerosol and spectral lidar and backscatter and extinction ratios of key aerosol types derived from selected Aerosol Robotic Network locations, J. Geophys. Res., 110, D10S11, doi:10.1029/2004JD005124, 2005.

Chandrasekhar, S.: Radiative Transfer, New York: Dover, 393 pp., 1960.

Chowdhary, J., Cairns, B., Mishchenko, M. I., Hobbs, P. V., Cota, G., Redemann, J., Rutledge, K., Holben, B. N., and Russell, E.: Retrieval of aerosol scattering and absorption properties from photopolarimetric observations over the ocean during the Chesapeake Lighthouse and Aircraft Measurements for Satellite (CLAMS) experiment, J. Atmos. Sci., 62(4), 1093-1117, 2005.

Clarke, A., McNaughton, C., Kapustin, V., Shinozuka, Y., Howell, S., Dibb, J., Zhou, J., Anderson, B., Brekhovskikh, V., Turner, H., and Pinkerton, M.: Biomass Burning and Pollution Aerosol over North America: Organic Components and their influence on Spectral Optical Properties and Humidification Response, J. Geophys. Res., 112, D12S18, doi:10.1029/2006JD007777, 2007

Corr, C. A., Krotkov, N., Madronich, S., Slusser, J. R., Holben, B., Gao, W., Flynn, J., Lefer, B., and Kreidenweis, S. M.: Retrieval of aerosol single scattering albedo at ultraviolet wavelengths at the T1 site during MILAGRO, Atmos. Chem. Phys., 9, 58135827, 2009, http://www.atmos-chem-phys.net/9/5813/2009/.

DeCarlo, P. F., Dunlea, E. J., Kimmel, J. R., Aiken, A. C., Sueper, D., Crounse, J., Wennberg, P. O., Emmons, L., Shinozuka, Y., Clarke, A., Zhou, J., Tomlinson, J., Collins, D. R., Knapp, D., Weinheimer, A. J., Montzka, D. D., Campos, T., and Jimenez, J. L.: Fast airborne aerosol size and chemistry measurements above Mexico City and Central Mexico during the MILAGRO campaign, Atmos. Chem. Phys., 8, 4027-4048, 2008, http://www.atmos-chem-phys.net/8/4027/2008/.

Dubovik, O., and King, M. D.: A flexible inversion algorithm for retrieval of aerosol optical properties from Sun and sky radiance measurements, J. Geophys. Res., 105, 20673-20696, 2000.

Dubovik, O., Smirnov, A., Holben, B. N., King, M. D., Kaufman, Y. J., Eck, T. F. and Slutsker, I.: Accuracy assessment of aerosol optical properties retrieval from AERONET sun and sky radiance measurements, J. Geophys. Res., 105, 9791-9806, 2000.

Dubovik, O., Holben, B. N., Eck, T. F., Smirnov, A., Kaufman, Y. J., King, M. D., Tanré, D., and Slutsker, I.: Variability of absorption and optical properties of key aerosol types observed in worldwide locations, J. Atmos. Sci., 59, 590-608, 2002a.

Dubovik, O., Holben, B. N., Lapyonok, T., Sinyuk, A., Mishchenko, M. I., Yang, P., and Slutsker, I.: Non-spherical aerosol retrieval method employing light scattering by spheroids, Geophys. Res. Lett., 29(10), 1415, doi:10.1029/2001GL014506, 2002b.

Dubovik, O., Sinyuk, A., Lapyonok, T., et al.: Application of spheroid models to account for aerosol particle nonsphericity in remote sensing of desert dust, J. Geophys. Res., 111, D11208, doi:10.1029/2005JD006619, 2006.

Eck, T. F., Holben, B. N., Dubovik, O., et al.: Columnar aerosol optical properties at AERONET sites in central eastern Asia and aerosol transport to the tropical mid-Pacific, J. Geophys. Res., 110, D06202, doi:10.1029/2004JD005274, 2005.

Fast, J. D., de Foy, B., Acevedo Rosas, F., Caetano, E., Carmichael, G., Emmons, L., McKenna, D., Mena, M., Skamarock, W., Tie, X., Coulter, R. L., Barnard, J. C., Wiedinmyer, C., and Madronich, S.: A meteorological overview of the MILAGRO field campaigns, Atmos. Chem. Phys., 7, 2233-2257, 2007, http://www.atmos-chem-phys.net/7/2233/2007/.

Gyawali, M., Arnott, W. P.,, Lewis, and Moosmüller, H.: In situ aerosol optics in Reno, NV, USA during and after the summer 2008 California wildfires and the influence of absorbing and nonabsorbing coatings on spectral light absorption, Atmos. Chem. Phys., 9, 8007-8015.

Hess, M., Koepke, P., and Schult, I.: Optical properties of aerosols and clouds: The software package OPAC, B. Am. Meteorol. Soc., 80, 831-844, 1998.

Holben, B. N., Tanré, D., Smirnov, A., Eck, T. F., Slutsker, I., Chatenet, B., Lavenue, F., Kaufman, Y., Castle, J. V., Setzer, A., Markham, B., Clark, D., Frouin, R., Karneli, A., O'Neill, N. T., Pietras, C., Pinker, R., Voss, K., and Zibordi, G.: An emerging ground-based aerosol climatology: Aerosol Optical Depth from AERONET, J. Geophys. Res., 106, 12067-12097, 2001.

Hostetler, C. A., Ferrare, R. A., Hair, J. W., Rogers, R. R., Obland, M., Burton, S. P., Su, W., Cook, A. L., and Harper, D. B.: Observations from the NASA Langley airborne High Spectral Resolution Lidar and plans for active-passive aerosol-cloud retrievals, Department of Energy Aerial Vehicle Program Workshop on Advances in Airborne Instrumentation for Measuring Aerosols, Clouds, Radiation and Atmospheric State Parameters, Urbana-Champaign, IL, 14-16 October 2008.

IPCC, 2007: Climate Change 2007: The Physical Science Basis. Contribution of Working Group I to the Fourth Assessment Report of the Intergovernmental Panel on Climate Change, edited by: Solomon, S., Qin, D., Manning, M., Chen, Z., Marquis, M. Averyt, K. B., Tignor, M., and Miller, H. L., Cambridge University Press, Cambridge, UK and New York, NY, USA, 996 pp., 2007.

Jacobson, M. Z.: Isolating nitrated and aromatic aerosols and nitrated aromatic gases as sources of ultraviolet light absorption, J Geophys. Res., 104, 3527-3542, 1999.

Kaufman, L. and Rousseeuw, P.; Finding Groups in Data, J. Wiley, Hoboken, NJ, USA, 338 pp., 1990.

Kaufman, Y. J., Tanré, D., and Boucher, O.: A satellite view of aerosols in the climate system. Nature, 419, 215-223, 2002.

Kirchstetter, T. W., Novakov, T., and Hobbs, P.: Evidence that the spectral dependence of light absorption by aerosols is affected by organic carbon, J. Geophys. Res., 109, D21208, 
doi:10.1029/2004JD004999, 2004.

Koepke, P., Hess, M., Schult, I., and Shettle, E. P.: Global aerosol data set. MPI Meteorologie Hamburg Report No. 243, 44 pp, 1997.

Lack, D. A. and Cappa, C. D.: Impact of brown and clear carbon on light absorption enhancement, single scatter albedo and absorption wavelength dependence of black carbon, Atmos. Chem. Phys. Discuss., 10, 785-819, 2010,

http://www.atmos-chem-phys-discuss.net/10/785/2010/.

Levy, R., Remer, L., and Dubovik, O.; Global aerosol optical models and application to MODIS aerosol retrieval over land, J. Geophys. Res., 112, D13210, doi:10.1029/2006JD007815, 2007.

Lewis, K., Arnott, W. P., Moosmuller, H., and Wold, C. E.: Strong spectral variation of biomass smoke light absorption and single scattering albedo observed with a novel dual-wavelength photoacoustic instrument, J. Geophys. Res., 113, D16203, doi:10.1029/2007JD009699, 2008.

Marley, N. A., Gaffney, J. S., Tackett, M., Sturchio, N. C., Heraty, L., Martinez, N., Hardy, K. D., Marchany-Rivera, A., Guilderson, T., MacMillan, A., and Steelman, K.: The impact of biogenic carbon sources on aerosol absorption in Mexico City, Atmos. Chem. Phys., 9, 1537-1549, 2009

Martins, J. V., Artaxo, P., Kaufman, Y. J., Castanho, A. D., and Remer, L. A.: Spectral absorption properties of aerosol particles from 350-2500 nm, Geophys. Res. Lett., 36, L13810, doi:10.1029/2009GL037435, 2009.

Massoli, P., Bates, T. S., Quinn, P. K., Lack, D. A., Baynard, T., Lerner, B. M., Tucker, S. C., Brioude, J., Stohl, A., and Williams, E. J.: Aerosol optical and hygroscopic properties during TexAQS-GoMACCS 2006 and their impact on aerosol direct radiative forcing, J. Geophys. Res., 114, D00F07, doi:10.1029/2008JD011604, 2009.

Matsumoto, T., Russell, P., Mina, C., Van Ark, W., and Banta, V.: Airborne Tracking Sunphotometer, J. Atmos. Ocean. Tech., 4, 336-339,1987.

McMeeking, G. R.: The Optical, Chemical, And Physical Properties Of Aerosols And Gases Emitted By The Laboratory Combustion Of Wildland Fuels, Dissertation, Department of Atmospheric Science, Colorado State University, Fort Collins, Colorado Fall 2008.

McMeeking, G., Petters, M., Carrico, K., Sullivan, A., Holden, M., Collett, J., Kreidenweis, S., Moosmüller, H., Arnott, P., Lewis, K., Wold, C., Hao, W. M., Malm, W., Kirchstetter, T., and Lunden, M.: Characterization of emissions from the laboratory combustion of wildland plant species, Int'l Conf. Carbonaceous Particles in the Atmosphere, Berkeley, CA, USA, 12-14 August 2008.

Mishchenko, M., Cairns, B., Kopp, G., Schueler, C., Fafaul, B., Hansen, J., Hooker, J., Itchkawich, T., Maring, H., and Travis, L. D.: Accurate Monitoring of terrestrial aerosols and total solar irradiance, B. Am. Meteorol. Soc., 88(5), 677-691, 2007.

Myhre, G.: Consistency between satellite-derived and modeled estimates of the direct aerosol effect, Science, 325 187-190, 2009.

Omar, A., Won, J.-G., Winker, D. M., Yoon, S.-C., Dubovik, O., and McCormick, M. P.: Development of global aerosol models using cluster analysis of aerosol Robotic Network (AERONET) measurements, J. Geophys. Res., 110, D10S14, doi:10.1029/2004JD004874, 2005.

Pilewskie P., Rabbette, M., Bergstrom, R., Marquez, J., Schmid, B., and Russell, P. B.; The discrepancy between measured and modeled downwelling solar irradiance at the ground: Dependence on water vapor, Geophys. Res. Lett., 27, 137-140, 2000.

Pilewskie, P., Pommier, J., Bergstrom, R., et al.: Solar spectral radiative forcing during the Southern African Regional Science Initiative, J. Geophys. Res., 108(D13), 8486, doi:10.1029/2002JD002411, 2003.

Reagan, J. A., Wang, X., Cattrall, C., and Thome, K.: Spaceborne lidar aerosol retrieval approaches based on aerosol model constraints, in Geoscience and Remote Sensing Symposium, 2004 IGARSS 04. Proceedings, 1940-1943, 2004.

Redemann, J., Pilewskie, P., Russell, P. B., Livingston, J. M., Howard, S., Schmid, B., Pommier, J., Gore, W., Eilers, J., and Wendisch, M.: Airborne measurements of spectral direct aerosol radiative forcing in the Intercontinental chemical Transport Experiment/Intercontinental Transport and Chemical Transformation of anthropogenic pollution, 2004, J. Geophys. Res., 111, D14210, doi:10.1029/2005JD006812, 2006.

Roden, C. A., Bond, T. C., Conway, S., Benhamin, A., and Pinel, O.: Emission factors and real-time optical properties of particles emitted from traditional wood burning cookstoves, Environ. Sci. Technol., 40, 6750-6757, 2006.

Russell, P., Livingston, J., Schmid, B., Eilers, J., Kolyer, R., Redemann, J., Ramirez, S., Yee, J.-H., Swartz, W., Shetter, R., Trepte, C., Risley Jr., A., Wenny, B., Zawodny, J., Chu, W., Pitts, M., Lumpe, J., Fromm, Randall, M. C., Hoppel, K., and Bevilacqua, R.: Aerosol optical depth measurements by airborne Sun photometer in SOLVE II: Comparisons to SAGE III, POAM III and airborne spectrometer measurements, Atmos. Chem. Phys., 5, 1311-1339, 2005

Russell, P. B., Livingston, J. M., Redemann, J., Schmid, B., Ramirez, S. A., Eilers, J., Khan, R., Chu, A., Remer, L., Quinn, P. K., Rood, M. J., and Wang, W.: Multi-GridCell Validation of Satellite Aerosol Property Retrievals in INTEX/ITCT/ICARTT 2004, J. Geophys. Res., 112, D12S09, doi:10.1029/2006JD007606, 2007.

Salcedo, D., Onasch, T. B., Dzepina, K., Canagaratna, M. R., Zhang, Q., Huffman, J. A., DeCarlo, P. F., Jayne, J. T., Mortimer, P., Worsnop, D. R., Kolb, C. E., Johnson, K. S., Zuberi, B., Marr, L. C., Volkamer, R., Molina, L. T., Molina, M. J., Cardenas, B., Bernab, R. M., Mrquez, C., Gaffney, J. S., Marley, N. A., Laskin, A., Shutthanandan, V., Xie, Y., Brune, W., Lesher, R., Shirley, T., and Jimenez, J. L.: Characterization of ambient aerosols in Mexico City during the MCMA-2003 campaign with Aerosol Mass Spectrometry: results from the CENICA Supersite, Atmos. Chem. Phys., 6, 925-946, 2006,

http://www.atmos-chem-phys.net/6/925/2006/.

Sandradewi, J., Prevot, A. S. H., Szidat, S., Perron, N., Rami Alfarra, M., Lanz, V. A., Weingartner, E., and Baltensparger, U.: Using Aerosol Light Absorption Measurements for the Quantitative Determination of Wood Burning and Traffic Emission Contributions to Particulate Matter, Environ. Sci. Technol., 42, 33163323, 2008.

Schnaiter, M., Horvath, H., Mohler, O., Naumann, K. H., Saathoff, H., and Schock, O. W.: UV-VIS-NIR spectral optical properties of soot and soot-containing aerosols, J. Aerosol Sci., 34, 14211444, 2003.

Schnaiter, M., Gimmler, M., Llamas, I., Linke, C., Jäger, C., and Mutschke, H.: Strong spectral dependence of light absorption by 
organic carbon particles formed by propane combustion, Atmos. Chem. Phys., 6, 2981-2990, 2006,

http://www.atmos-chem-phys.net/6/2981/2006/.

Schuster G., O. Dubovik, B. N. Holben, and E. E. Clothiaux, Inferring black carbon content and specific absorption from Aerosol Robotic Network (AERONET) aerosol retrievals, J. Geophys. Res., 110, No. D10, D10S17, 10.1029/2004JD004548, 2005.

Schuster, G. L., Lin, B., and Dubovik, O.: Remote sensing of aerosol water uptake, Geophys. Res. Lett., 36, L03814, doi:10.1029/2008GL036576, 2009.

Shettle, E. P. and Fenn, R. W.: Models of aerosols of lower troposphere and the effect of humidity variations on their optical properties. AFCRL Tech. Rep. 79 0214, Air Force Cambridge Res. Lab., Hanscom Air Force Base, Mass., 100 pp, 1979.

Shinozuka, Y., Clarke, A., Howell, S., et al.: Relations Between Cloud Condensation Nuclei And Aerosol Optical Properties Relevant to Remote Sensing: Airborne Measurements in Biomass Burning, Pollution and Dust Aerosol Over North America, Eos Trans. AGU, 89(53), Fall Meet. Suppl., Abstract A41E-0164, 2008.

Shinozuka, Y., Clarke, A. D., DeCarlo, P. F., Jimenez, J. L., Dunlea, E. J., Roberts, G. C., Tomlinson, J. M., Collins, D. R., Howell, S. G., Kapustin, V. N., McNaughton, C. S., and Zhou, J.: Aerosol optical properties relevant to regional remote sensing of $\mathrm{CCN}$ activity and links to their organic mass fraction: airborne observations over Central Mexico and the US West Coast during MILAGRO/INTEX-B, Atmos. Chem. Phys., 9, 6727-6742, 2009, http://www.atmos-chem-phys.net/9/6727/2009/.

Sierau, B., Covert, D. S., Coffman, D. J., Quinn, P. K., and Bates, T. S.: Aerosol optical properties during the 2004 New England Air Quality Study - Intercontinental Transport and Chemical Transformation: Gulf of Maine surface measurements Regional and case studies, J. Geophys. Res., 111, D23S37, doi:10.1029/2006JD007568, 2006.

Tanré D., Remer, L. R., Kaufman, Y. J., Mattoo, S., Hobbs, P. V., Livingston, J. M., Russell, P. B., and Smirnov, A.: Retrieval of aerosol optical thickness and size distribution over ocean from the MODIS airborne simulator during TARFOX, J. Geophys. Res., 104, 2261-2278, 1999.
Torres O., Bhartia, P. K., Herman, J. R., and Ahmad, Z.: Derivation of aerosol properties from satellite measurements of backscattered ultraviolet radiation. Theoretical Basis, J. Geophys. Res., 103, 17099-17110, 1998.

Torres, O., Bhartia, P. K., Syniuk, A., and Welton, E.: TOMS Measurements of Aerosol Absorption from Space: Comparison to SAFARI 2000 Ground based Observations, J. Geophys. Res., 110, D10S18, doi:10.10129/2004JD004611, 2005.

Virkkula, A., Ahlquist, N. C., Covert, D. S., Arnott, W. P., Sheridan, P. J., Quinn, P. K., and Coffman, D. J.: Modification, calibration and a field test of an instrument for measuring light absorption by particles, Aerosol Sci. Technol., 39(1), 68-83, 2005.

WMO: Radiation commission of IAMAP meeting of experts on aerosol and their climatic effects. WCP55, Williamsburg VA, 2830, 1983.

Yang, M., Howell, S. G., Zhuang, J., and Huebert, B. J.: Attribution of aerosol light absorption to black carbon, brown carbon, and dust in China - interpretations of atmospheric measurements during EAST-AIRE, Atmos. Chem. Phys., 9, 2035-2050, 2009, http://www.atmos-chem-phys.net/9/2035/2009/.

Yu, H., Chin, M., Remer, L. A., Kleidman, R. G., Bellouin, N., Bian, H., and Diehl, T.: Variability of marine aerosol finemode fraction and estimates of anthropogenic aerosol component over cloud-free oceans from the Moderate Resolution Imaging Spectroradiometer (MODIS), J. Geophys. Res., 114, D10206, doi:10.1029/2008JD010648, 2009.

Zhang, Q., Jimenez, J. L., Canagaratna, M. R., et al.: Ubiquity and Dominance of Oxygenated Species in Organic Aerosols in Anthropogenically-Influenced Northern Hemisphere Mid-latitudes. Geophys. Res. Lett., 34, L13801, doi:10.1029/2007GL029979. 